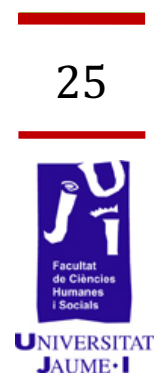

\title{
The Status of Universal Human Rights in the 21st Century: An Appraisal
}


The emergence of human rights into human ethical consciousness and their development and now worldwide recognition constitutes a moral phenomenon of astonishing scale and unparalleled significance, well meriting the remark of Henkin (1990: p.xvii) that "Ours is the age of human rights. Human rights is the idea of our time (Mahoney, 2007: viii).

On $10^{\text {th }}$ December, 1948 , the famous Universal Declaration of Human Rights (UDHR) was proclaimed as one of the most widespread and globally binding internationally-recognized human rights document in the horrendous aftermath of the First World War. Its universal importance is seen in the recognition of the day as International Human Rights Day, and celebrated as such throughout the world. One of the principal objectives then was to avert a repetition of the holocaust, and to safeguard the provision of human rights contained in this document. Dinah L. Shelton places significant emphasis on this for good reasons. As she notes, "the concept of human rights involves consideration of what "rights" a person possesses by virtue of being "human", that is rights that human beings, independent of the infinite variety of individual characteristics and human social circumstances" (Shelton, 2014: 1). The essence of this emphasis, especially her emphasis on "infinite" human characteristic, is perhaps, to safeguard future generations from the challenges of "identity" and the idea of "us" versus "them" often used in cases of "just wars". It is the development of this aspect which this article seeks to investigate, using circumstances of the Ebola virus threat as a reference point. The article concludes that, there are emerging threats that question the extent of universality

\section{The Ideals of Human Rights}

The ideas inherent human rights are neither new nor arbitrary. They come from principal actors, who themselves, come from multidisciplinary and wide-ranging fields including economics, gender, history, international law, international relations, philosophy, religion, and politics. It is not wrong to suggest that, it is this broad-based sectorial involvement of society that has helped shape the scope, coverage and consequent universality of human rights. In many respects too, human rights make cases for the governors and the governed alike. Human Rights come with the strength and merit of serving as concrete expression of the inherent worthiness of every person, and also make up for the ideal components needed for a dignified life. It is from such informed backgrounds that the likes of John Locke, Immanuel Kant and countless other thinkers made century-old submissions that are still as relevant today as the times that they were made. Origins of Human Rights are also traceable to worldacclaimed historical documents and political events including the Hamorabi Code, the English Bill of Rights 1689, the Magna Carta Carta 
Libertatum, properly known as the Great Charter of Freedoms, of 1215 as well as the French Revolution and the 1748 Declaration des droits de I'homme. All these sources exemplified some common characteristics. Among them, limiting the powers of rulers and bringing them in line with the common man at least in terms of equality before International Human Rights Law (IHRL). More important to this discussion, however, establishing a common yardstick with which the equality of all human beings could be measured, if international justice is to prevail.

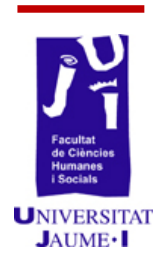

\section{The Human Rights Paradigm}

In the realms of theory, it can be said without the fear of being proved wrong that the concept of human rights has enjoyed significant global prominence since it emerged on the international agenda. The United Nations (UN) and its agencies worldwide, has been at the forefront of protecting, promoting and facilitating the enjoyment of human rights. It has already been more than half a century since the UDHR was proclaimed to the effect that all men (and I would like to add "and all women") are created equal irrespective of creed, race, religion, nationality or gender among others. Such human rights tenets have since been protected and preserved under what is known today as international human rights law. As explained later in this article, such universal human rights did not just come out of the blue. Besides, there have been increasing props such as the emergence of Conventions, Solemn Declarations, Optional Protocols and Treaty Bodies, all in a bid to support and strengthen human rights norms.

\section{Initial Challenges}

In April 2003, M.E. Sharp published Joanne Bauer's Construction of Human Rights in the Age of Globalization where the author recounted that a commonly held notion among Western liberals at the emergence of Human Rights was that Asian, African, and Arab perspectives on the concept were the greatest challenge to the universality of human rights. It was felt that, once the international human rights community reckoned with the countries of these outlier regions, it would have overcome this obstacle to universal human rights. Unfortunately, this idea, for many reasons, was a heavy error of judgment. In fact, this idea was either oblivious or ignorant that even within the West where the protagonists of human rights emerged, there are significant numbers of people who hold ideas of human rights that are in tension with the dominant liberal interpretation of international human rights, and the fact that within Asia, Africa, and the Arab world there are strong traditions that are consistent with it. 
In spite of all the recognitions, codification, protection and jurisdiction of internationally-recognized human rights, they have not been immune to subtle and open abuses and violations, some in private while others in broad day light. Some norms of human rights, especially as they relate to womanhood and women's values have been continuously desecrated on the delicate altar of cultural and traditional "values". For example, Female Genital Mutilations (FGM) has been imposed on women in some parts of the world, and justified in the name of traditional value systems. In some Muslim communities, legal provisions make it more difficult, sophisticated and almost impossible for females to prove "rape". Sometimes, as many as three witnesses are demanded to prove rape! If these needed three witnesses were available to witness rape, they might as well have prevented it! Some justice systems are crafted in such a way that even in extra-marital affairs, females are almost summarily guilty while nothing or not much is said of their male counterparts. This trend is debilitating and sometimes outrageous. But it is getting even worse on the global scene. Because human rights are universal, this must be of concern to Muslims and non-Muslims alike, even as we all accord its practitioners the due respect they deserve in taking a free choice to practice their chosen religions. After 60 years of the UDHR, the circumstances that prevailed at the time of its establishment have changed drastically. Though that ought not to have been the case, a new world order poses significant threats and challenges to this international document. Dwelling on developments emerging as a result of the deadly Ebola virus, this article investigates contemporary status of human rights, especially viewed against the concept of state sovereignty, state protectionism within the context and framework of international relations.

\section{Further Challenges}

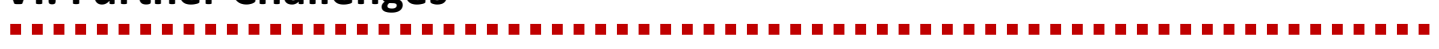

Since its inception, the idea of human rights has suffered several challenges. Among them, some critics have suggested that human rights are not well representative of all cultures, regions and practice. Africa is a typical proponent of this view, arguing that it was not involved in the framing of human rights. They have therefore questioned, for instance, how one single document of only 30 Articles, can claim to fairly and effectively represent all cultures, religions and value systems of the entire world. In many parts of Africa and Asia, the notion is still held that human rights are a product of the West, and that the idea of universalizing this western concept or product is only a plot to subjugate the rest of the world to the whims and ideological interest of the West, who are the proponents of human rights, in order to impose their cultures and believes on others. In furtherance of this argument, it has been held that human rights, 
because they are the product of the West, they undermine some local cultural traditions in other parts of the world where human rights are not akin to their practices. In some cases therefore, one perceives an incipient clash between the place of human rights and that of cultural value systems.

Another case worth the world's attention is that, for a long time now, it has been argued that, institutions, notably the International Criminal Court (ICC) which is supposed to be the international police of human rights, is rather serving as a tool for targeting African leaders. The Africans have outlined many arguments to support this. Perhaps chief among them, almost all indictees of the ICC so far are Africans: From Charles Taylor through Omar Al Bashir of Sudan to Kenya's president (New African, March, 2012: 26-29). Never mind that the ICC has recently withdrawn interest in the Kenyan inictee. Whether their crimes rightly fall within the ambit and jurisdiction of the ICC has not necessarily been the bone of contention. The issue that has prevailed is why other potentially guilty people from other parts of the world have not been hauled before this authoritative ICC. It is the view of many that, the likes of George Bush have excellent potential candidature for the ICC, yet the ICC simply does not possess the gut to contemplate investigating them. It is also a widely-held view, that the continued existence of the famous or infamous Guantanamo Bay flies against international human rights yet the ICC appears either powerless or uninterested in dealing with it or has turned deaf ears and blind eyes to this, as it folds its poor tails between its hind legs in the face of Guantanamo Bay. To what extent are human rights truly universal?

There are several instances of such perceived flagrant injustices, too numerous to be listed under this engagement. However, this article is more concerned with a new breed, or variant of threat to the status of international human rights law. It is the threat of human rights violations invoked by the emergence of the Ebola Virus, and apparently "justified" in the name of state sovereignty or state security. One of the centerpieces of international human rights is the idea of human dignity and equality. Permit me to reiterate the place of "dignity" and "equality", for it is this idea of universal human dignity and the universality of human rights which led the likes of the German philosopher Immanuel Kant to propound the cosmopolitan reasoning that when the human rights of anyone is violated anywhere, the rights of other people are violated elsewhere. This reasoning is so fundamental that Martin Luther King Jnr resonated comparable sentiments when he espoused that injustice anywhere is injustice everywhere.

Paolo Carozza (2013) reminds us that human dignity is one of the most fundamental concepts of international human rights law. As such, it appears in almost all human rights instruments and is regularly applied by human rights bodies. That the basis of human dignity is the basis of fundamental human rights is so well enshrined in the preamble of the UDHR thus "Recognition of the inherent dignity and of the equal and inalienable rights of all members of the human family is the foundation of freedom, justice and peace in the world". In my opinion, not at any point 
therefore should human dignity be violable because it is at the heart of the collective humanity we share. Without this human identity, all the protection provided by human rights mechanisms in favor of the human being risk having any meaning or substantive value. This far, it can now be ascertained that human dignity is not only a fundamental right but that it is establishes the legitimate place of human values in international human rights law and must therefore be respected even where it is restricted.

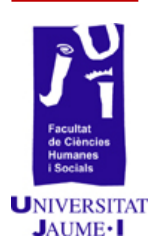

\section{The Ebola Virus as an Emerging Concern}

The Thursday, $6^{\text {th }}$ November, 2014 issue of El Pais, a daily newspaper of in Spain, carried on its front page, a publication titled: "Inmigrantes trasladados en un camion de basura". This translates into "Immigrants transported in a refuse truck". Really? Yes, and they all happened to be Africans. After 7 hours at the Maspaloma beach in the Canary Islands, these 23 immigrants were transported in the refuse truck to a "centro de acogida" by state agents, even though staff of the Red Cross, who were present rejected the idea on grounds that this was not how to handle human beings. It turned out that, the state authorities in question claimed that some of the immigrants had very high temperatures that suggested they could be suffering from the deadly Ebola virus. Of course, the outbreak of the Ebola virus in parts of West Africa at that time was the worst outbreak of the virus in its history. It had taken everyone by surprise, and no one was prepared for it in terms of vaccines or cure. Given its notorious mode of contamination, the best everyone could have done, admittedly, was to prevent body contacts with people suffering from Ebola virus. On account of this, no one would blame the concerned authorities at the Maspaloma beach on the Canary Islands for keeping these illegal immigrants who also happened to be suspected of having the deadly virus. After all, the immigrants have themselves to blame for using unauthorized routes and travelling possibly without appropriate documents. This in itself is a violation of international norms.

The point of departure of this article, however, is the dehumanizing thought of conveying them in a refuse truck! In spite of all the challenges associated with handling the Ebola, once can be certain that, if these immigrants were to be from some countries other than Africa, this situation could never have prevailed! One is therefore compelled to begin to think, smell and feel the huge presence of racism and discrimination in this state of affairs. Interestingly, this article never found any condemnation from any African government or embassy regarding this inhuman treatment of human beings meted to human beings by fellow human beings. First and foremost as a human being, then as a member of the black race, I feel heavily insulted by this act. For me, it is nothing other than a debasement of universal human values, and if this could pass so 
easily in our $21^{\text {st }}$ century when we preach globalization and universality of human rights, then there is something fundamentally shaky about what we view as international Human Rights Law (IHRL). This is even more so when this inhuman treatment was meted out on a mere "suspicion"!

There is no way any black country would have contemplated this against nationals of any non-white country for any reason. Yet, it happened as a normal thing when the black African is the recipient. But even worse, perhaps, the fat that hat no African country or embassy could condemn this act is to say the least, disgusting and opprobrious in extremes. Even if the suspects were truly suffering from Ebola virus, they did not deserve to be transported in a refuse truck. For goodness sake, even corps that have no life are not transported in trash vans. So, for this to happen to living human beings in the name of "state protectionism" or any other reason is an affront to human dignity and universal human rights, and ought to be condemned unreservedly. I hasten, but may I ask: Are African humans yet?

\section{Conclusion}

It is my humble view that the core principles inherent in human dignity and human values must be consistently explored towards helping the human race to regulate expansive interpretations of human rights and to solidify the central and non-negotiable importance of human dignity towards negotiating and constructing rather than de-constructing human dignity. This would help curtail the emerging exceptions that are being used to detract from the common good of humanity. The very nature of the Ebola virus and its mode of spread, coupled with the absence of a definitive cure at the moment make it a global scare but it must not be allowed to assume the status of justifying anyone's enjoyment of the inalienable right of human dignity accorded to all members of the human race. Let us not cultivate "Crimes Against Human Dignity"! 


\section{Bibliografia}

CAROZZA, Paolo (2013): "Human Dignity" in Oxford Handbook of Human UNAUME.I Rights

BAUER, Joanne "The Challenge of International human Rights" in Constructing Human Rights in the Age of Globalization, M.E. Sharp, 2003. Source: http://www.carnegiecouncil.org/publications/articles papers reports/905.htm l Retrieved: 12 $2^{\text {th }}$ January, 2015.

"New African", No. 514, (March, 2012): "ICC vs. Africa: The Scales of Injustice", IC Publications, London.

MAHONEY, Jack (2007): The Challenge of Human Rights: Origin, Development and Significance, Malden, Blackwell Publishing.

Shelton, Dinah L. (ed), (2013): The Oxford Handbook of International Human Rights Law, Oxford University Press,

Shelton, Dinah L. (2014): Advanced Introduction to International Human Rights Law, Edward Elgar Publishing Inc. Cheltenham. 
